\title{
Estimation of energy content in municipal solid waste of Bhutan and its potential as alternate powers source
}

\author{
Choden, Y. ${ }^{1}$, Tenzin, T. ${ }^{1}$, Karchung $^{2}$, Norbu, K. ${ }^{1}$, Wangmo, S. $^{1}$, Zangmo, ${ }^{1}$
}

\begin{abstract}
Conversion of Solid waste into energy is the most resourceful process to combat landfill saturation and environmental impression. Bhutan, with an exponential rise in the waste production, Waste to Energy (WTE) conversion is an alternative solution for municipal solid waste management (MSW). The study for MSW composition and its energy potential analysis for Memelakha (Thimphu) and Pekarshing (Phuntsholing) landfills was done to resolve the waste management challenges in the country. The standard number of samples from two dumpsites were used to analyze for the waste characterization (waste composition, proximate analysis, chemical analysis) and high heating value (HHV) of MSW. MSW of two landfills showed that the main elemental constituents were Carbon and Oxygen with $17.26 \%$ and 9.97\% by mass respectively for Pekarshing and 16.52\% (Carbon) and 11.07\% (Oxygen) by mass for Memelakha landfill. Based on the physio-chemical analysis of MSW, the average calorific HHV of MSW obtained were $10.028 \mathrm{MJ} / \mathrm{kg}(26.04 \%$ of coal energy) for Pekarshing dumpsite and $9.6 \mathrm{MJ} / \mathrm{kg}(24.94 \%$ of coal energy) for Memelakha. The analysis showed that by the year 2050 Memelakha landfill has the potential to generate the power of 8.85 Megawatt (MW) and 1.44 Megawatt (MW) for Pekarshing. For (WTE) conversion, incineration, pyrolysis, and gasification technologies are found suitable based on the current composition MSW of Bhutan. Furthermore, in terms of energy efficiency and percentage of wastage, the gasification process was the most feasible method for WTE conversion at two locations with a waste volume reduction of 80 to 90 percent at the landfill.
\end{abstract}

Key words: Chemical Analysis, Calorific Value, Municipal Solid Waste, Proximate Analysis, Waste to Energy

\section{Introduction}

Due to increase in population and its exponential increase in solid waste generation, developing countries are majorly affected because of disposing of waste in unregulated dumps, openly burning the waste which causes serious health issues and environmental pollution (Gupta et al., 1998). World bank waste generation forecast report states, by 2025 there will be waste production of 2.2 billion tons per year around the world. Unless an efficient waste management plan is implemented, these bulk quantities of waste could result in emission of a massive quantity of greenhouse gases, environmental degradation, and health hazard to inhabitants (World bank, 2018). Landfilling is the most popular waste dumping method adopted by developing nations to dump waste and $90 \%$ of landfills do not have landfill gas (LFG) collection systems. Consequently, the landfills are the

\section{Author's Address}

${ }^{1}$ College of Science and Technology, Royal University of Bhutan.

${ }^{2}$ Phodrang real estate company Thimphu, Bhutan

E-mail.: yeshichoden65@gmail.com largest anthropogenic contributors to greenhouse gases , non-methane pollutants, leachate and production of foul odor which contribute to major environmental pollution (Agamuthu, 2013). According to the IPCC annual reports, improper waste management is the main factor causing increase in GHG emissions, along with the leachate production from those landfills which further contribute in pollution of underground water (Eggleston et al., 2007). Many countries such as Indonesia, China, Vietnam etc., having faced issues of increase in waste production, have opted waste management as a solution, with investment on sustainable disposal sites engineered with gas collection systems and organic waste are managed by directly feeding into anaerobic digestion facilities recovering biogas as energy (Manuja et al. 2018). Bhutan is a small landlocked country positioned between China in the north and India in the east, west, and south with an area of $38,394 \mathrm{~km}^{2}$ (GNHC, 2000). It has 20 districts, from which Phuentsholing (15.6 $\mathrm{km}^{2}$ area) and Thimphu (26.1 $\mathrm{km}^{2}$ area) are the two major cities. Bhutan is a 


\section{Choden et al.}

developing country with rapid growth in socioeconomic and population. According to the report 2017 Population and Housing Census of Bhutan, Bhutan has a population of 7,35,553 with $62.2 \%$ living in the urban areas and 37.8\% living in the rural areas. From all the dzongkhag, Thimphu has the highest population, $1,38,736$ which is $19.1 \%$ of the total population and Phuentsholing has 27,658 people living in it which constitute $3.76 \%$ of the total population. From the year 2005 to 2017 , there was a $16 \%$ increase in the population (National Statistics Bureau, 2018). The increase in population, urban development, and change in lifestyle have greatly influenced the generation of solid waste (Phuntsho et al., 2010). The National Environment Commission has reported that, with rapid socio-economic development, increasing population and urbanization, the country is seeing an increase in the amount of solid waste generation. More problematically the composition of that waste is shifting from biodegradable to non-biodegradable waste (National Environment Commission, 2016). Many developed countries have a good pace in managing MSW in an environmental friendly way. One of the common methods is to adopt an integrated solid waste management system. Where Reduce, Segregation, Recycle and Reuse are given first priority and some are used to extract energy. Some of the success stories behind the Waste to Energy (WTE) technology in the production of energy are $53 \mathrm{MW}$ electricity generation by incinerating 636 tons per day at $982^{\circ} \mathrm{C}$, Energy Recovery Facility in the UK located at Sheffield is able to supply heat for District Network (Moya et al., 2017) . It can also produce ethanol, methane, hydrogen, and syngas through the biotechnological and thermochemical processes (Matsakas et al., 2017). A case study on MSW generated in Roorkee city, India, was analysed based on its physical and chemical composition. The energy content in MSW from analysis resulted to $2124 \mathrm{Kcal} / \mathrm{kg}$. Potential power generation from dry and solid waste of the city was determined and results showed that MSW of the city could generate energy of $28248 \mathrm{Kwh}$ which is enough to light 9000 street lights for 12 hours (Choden and Sharma, 2020).

Studies have been reported on types of waste generated in Bhutan but with limited research done on the energy content of its MSW. This research aims to study the potential of MSW as an alternative source of energy and a possible waste management solution, taking landfill sites of two biggest cities of country as study area. The paper presents the analysis of waste in terms of physiochemical properties and energy potential of MSW of Bhutan. The output presented in this study would serve as valuable technical data for waste managers/ implementers basing on actual site data.

\section{Materials and Methods Site Description}

Memelakha was identified as the waste dumping site in 1994 with the design period of 8 years. All the MSW from Thimphu city is dumped in the Memelakha landfill area, which is located $10 \mathrm{kms}$ away from Thimphu city towards Wangdue Phodrang. Memelakha landfill is still active with the construction of leachate collection tanks and vent pipes for the removal of methane gas. Compaction and covering of waste are practiced to reduce the volume of waste and increase the lifespan of the landfill (RSPN, 2018). The Pekarshing area is used for dumping the MSW of Phuentsholing city. Construction work of the landfill was completed in the year 2005. It is located at $7 \mathrm{kms}$ away from the Phuentsholing thromde towards the Pasakha with a total designated area of 7.2 sq.km, out of which only 1.2 sq.km area is used as a landfilling site. The design capacity of the landfill is 24 metric tons per day $(\mathrm{mt} / \mathrm{d})$ with a design period of 10 years. The Annual average precipitation of Phuentsholing is 4979.4 $\mathrm{mm}$ (GNHC, 2019). During the peak monsoon season, the average maximum temperature reaches $29^{\circ} \mathrm{C}$ and the average minimum temperature is 19.3 ${ }^{\circ} \mathrm{C}$. The landfill area has no proper design and provision kept for the collection of leachate and for release of methane $\left(\mathrm{CH}_{4}\right)$ gas to the atmosphere. This landfill has already exceeded the design period and it is under a rectification process. Embankment around the landfill site is constructed using MSW as embankment material (Penjor, 2019; Rai, 2021).

\section{Sample collection and composition of MSW}

For the waste generation analysis, the Population data from NEC survey, year 2005 to 2017 is used (RGOB, 2017). The population for the year 2050 is projected using an arithmetic method. Along with the population projection, a waste generation forecast has also been carried out. Sample 
collection and waste composition analysis is carried out with reference to the (ASTM D5231-92, 2003). For the sampling, 10 locations were chosen such that the whole area of landfill was covered. Then samples were collected from all the locations with varying depths. Each sample weight was noted on wet received basis and oven dried for 24 hours to determine moisture content. After an oven dried, each composition of MSW was calculated in terms of percentage by weight and then energy content was determined.

\section{Proximate analysis}

The Proximate analysis gives percentage content of moisture, ash (inorganic waste material), volatile matter (material that burns in a gaseous state) and fixed carbon (solid-state). From which the High heating value of municipal solid waste is determined using standard procedure (Sahito et al., 2013). Approximately 1gram of shredded sample passed through $1 \mathrm{~mm}$ size sieve, was oven dried for 2 hours at $105^{\circ} \mathrm{C}$. The difference of weight of final and initial weight represents the moisture content of the MSW. Volatile matter content test is determined with reference to (ASTM E872-82, 2019). Samples from the moisture content test are reheated at $950^{\circ} \mathrm{C}$ for 2 hours in a muffle furnace, the difference of initial and final weight gives the volatile content of the MSW and is represented in terms of percentage by weight. The most volatile matter comes from the organic components and common constituents are water, carbon dioxide and sulfur dioxide. Volatile matter in the MSW has a positive effect on the energy potential. High content of Volatile matter represents the amount of combustible matter present in the waste. Ash is to determine the inorganic residue left after the sample is completely burned as per (ASTM E1755 2020). Samples from the volatile matter content test are reheated to $575^{\circ} \mathrm{C} \pm 25^{\circ} \mathrm{C}$ for 2-hours. Difference of initial and final weight gives the ash content of the MSW and is represented in terms of percentage by weight. As of fixed carbon, it determines only solid carbon found in the form of char after the devolatilization determined as per (ASTM D5231-92, 2003). Calorific value has been obtained using Standard bomb calorimeter (D240-19, 2019).

\section{Chemical analysis}

Chemical analysis was carried out for MSW of two landfill sites in order to determine the elemental standard values of MSW, referring to the work of
(Menikpura et al., 2007). Results from chemical analysis were used to determine elemental composition of the combustible portion of MSW of Roorkee city

\section{Results and Discussion}

Pekarshing landfill has a maximum composition of glass, with $40 \%$ and minimum of textile with $5 \%$ by weight in MSW. Similarly, Memelakha landfill constitutes maximum waste composition of paper with $33 \%$ by weight. Figure $1 \& 2$, shows the waste composition of Pekarshing and Memelakha landfills respectively. From the physical composition analysis, the calorific value of the MSW is $10.527 \mathrm{MJ} / \mathrm{kg}$ for Pekarshing landfill and $16.510 \mathrm{MJ} / \mathrm{kg}$ for Memelakha landfill.

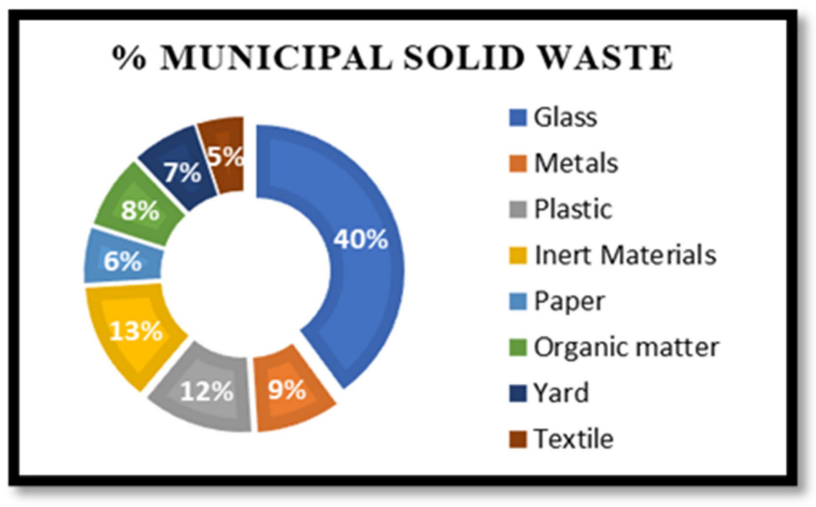

Figure 1: Waste composition Pekarshing

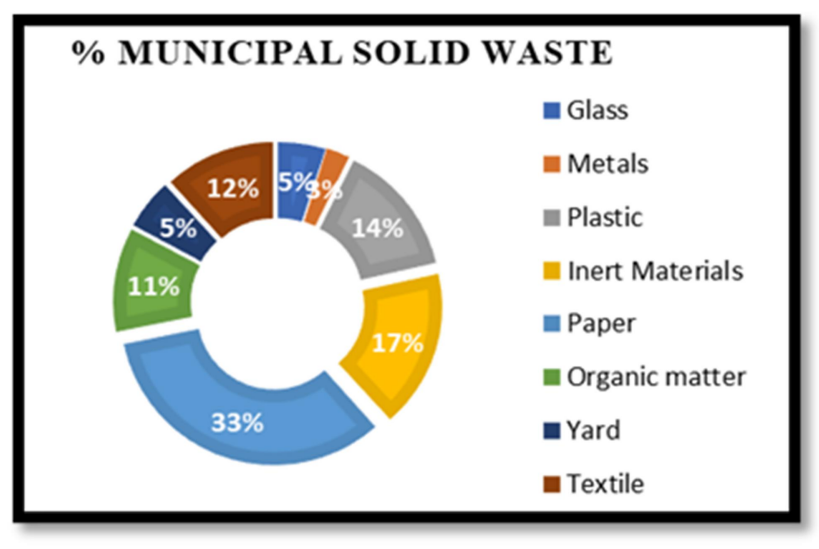

Figure 2: Waste composition Memelakha

Proximate and chemical analysis were conducted after waste composition analysis. The results obtained from the proximate analysis (Refer Figure $3 \& 4)$ are $11.55 \mathrm{MJ} / \mathrm{kg}$ for Pekarshing and 7.47 $\mathrm{MJ} / \mathrm{kg}$ for Memelakha landfill. Similarly, for 
chemical analysis, an example of detailed elemental composition of one of the landfills (Pekarshing) is shown in table 1 in terms of weight $(\mathrm{Kg})$. Similar elemental composition analysis for Memelakha was performed and then elemental composition was converted into $\%$ by mass for both landfills as shown in Figure 5. Based on chemical analysis, energy potential of $6.72 \mathrm{MJ} / \mathrm{kg}$ and $6.104 \mathrm{MJ} / \mathrm{kg}$ for Pekarshing and Memelakha dumpsites are found respectively (Refer Figure 6).

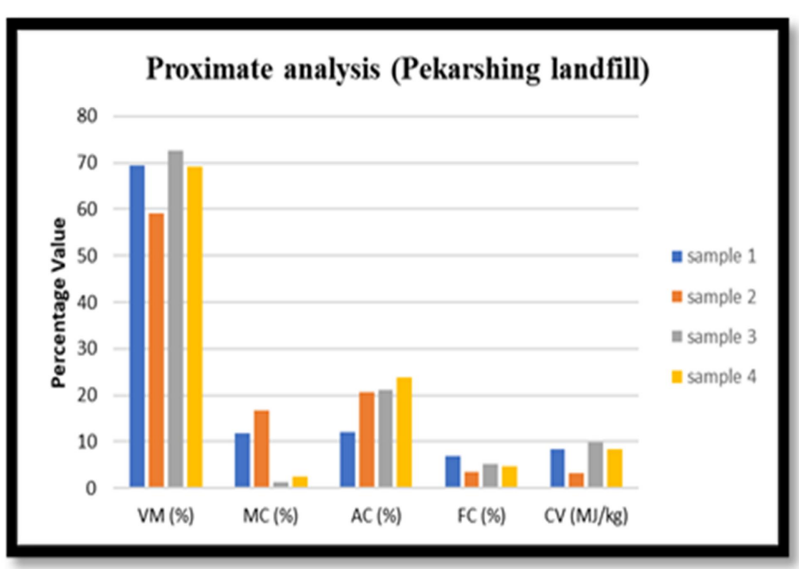

Figure 3: proximate analysis (Pekarshing)

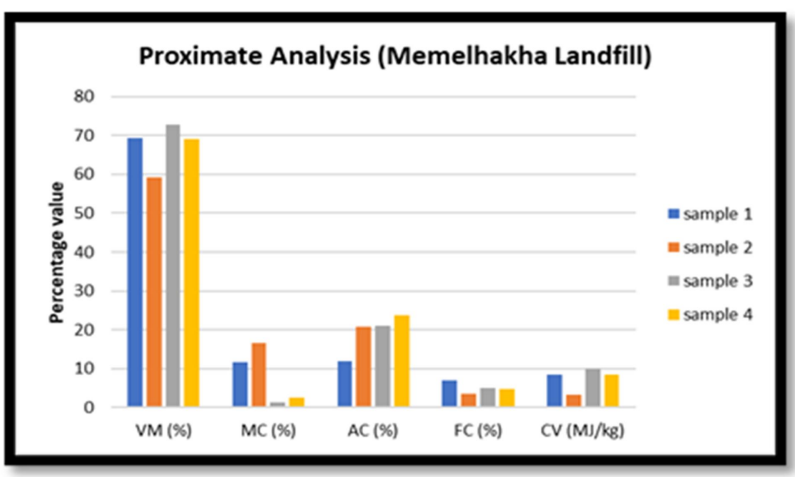

Figure 4 : proximate analysis (Memelakha)

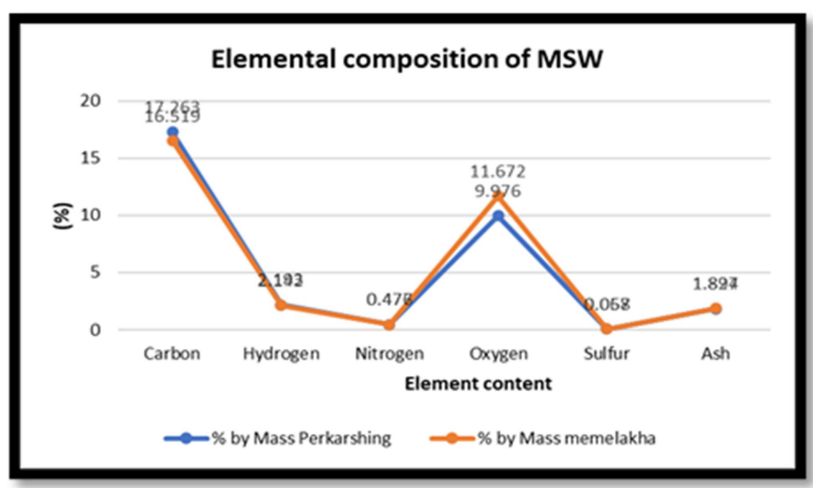

Figure 5: Mass in \% of Element content in MSW

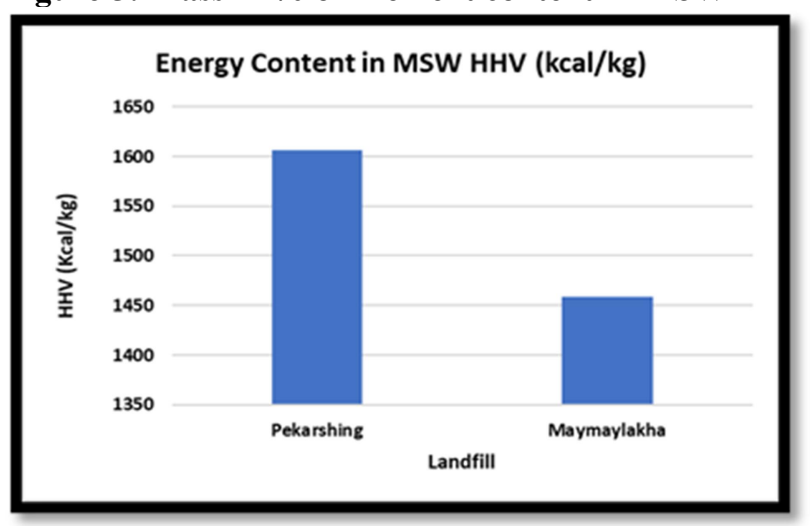

Figure 6 : Energy content in kcal/kg.

From the three analyses shown in Table 2, the average energy potentials of Pekarshing and Memelakha landfills are $9.6 \mathrm{MJ} / \mathrm{kg}$ and 10.028 $\mathrm{MJ} / \mathrm{kg}$ respectively. From the composition perspective, Pekarshing landfill has a maximum percentage of paper and plastic. The HHV for Pekarshing is lower than that of Memelakha. Coal has an average energy potential of $38.5 \mathrm{MJ} / \mathrm{kg}$ (van Prevelen, 2007)(University of Washington 2005), thus in comparison to coal energy, Pekarshing can generate $24.94 \%$ of inherent coal capacity and 26.05\% for Memelakha.

Table 1: Example of Elemental Composition of MSW analyzed in terms Kg ( Pekarshing Landfill)

\begin{tabular}{|l|l|l|l|l|l|l|l|l|}
\hline $\begin{array}{l}\text { Waste } \\
\text { composition }\end{array}$ & $\begin{array}{l}\text { Wet Waste } \\
(\mathbf{K g})\end{array}$ & $\begin{array}{l}\text { Dry Waste } \\
(\mathbf{k g})\end{array}$ & $\begin{array}{l}\text { Carbon } \\
(\mathbf{K g})\end{array}$ & $\begin{array}{l}\text { Hydrogen } \\
(\mathbf{K g})\end{array}$ & $\begin{array}{l}\text { Nitrogen } \\
(\mathbf{K g})\end{array}$ & $\begin{array}{l}\text { Oxygen } \\
(\mathbf{K g})\end{array}$ & $\begin{array}{l}\text { Sulfur } \\
(\mathbf{K g})\end{array}$ & $\begin{array}{l}\text { Ash } \\
(\mathbf{K g})\end{array}$ \\
\hline Food Waste $(\mathrm{Ga})$ & 0.714 & 0.582 & 0.279 & 0.037 & 0.015 & 0.219 & 0.002 & 0.029 \\
\hline Paper $(\mathrm{Pa})$ & 0.76 & 0.619 & 0.269 & 0.037 & 0.002 & 0.272 & 0.001 & 0.037 \\
\hline Textile (Te) & 0.446 & 0.363 & 0.2 & 0.024 & 0.017 & 0.113 & 0.001 & 0.009 \\
\hline Plastic (Pl) & 0.626 & 0.51 & 0.306 & 0.037 & 0 & 0.116 & 0 & 0.051 \\
\hline Wood (Wo) & 0.484 & 0.394 & 0.195 & 0.024 & 0.001 & 0.001 & 0 & 0.006 \\
\hline Total & 2.468 & 2.468 & 1.249 & 0.159 & 0.034 & 0.722 & 0.004 & 0.132 \\
\hline
\end{tabular}


Estimation of energy content in municipal solid waste

Table 2: Average energy content of the two landfills

\begin{tabular}{|l|l|l|l|l|l|}
\hline $\begin{array}{l}\text { Landfill } \\
\text { Location }\end{array}$ & $\begin{array}{l}\text { Waste composition } \\
\text { analysis (MJ/kg) }\end{array}$ & $\begin{array}{l}\text { Proximate analysis } \\
\text { (MJ/kg) }\end{array}$ & $\begin{array}{l}\text { Chemical Analysis } \\
\text { (MJ/kg) }\end{array}$ & $\begin{array}{l}\text { Average } \\
\text { (MJ/kg) }\end{array}$ & $\begin{array}{l}\text { HHV of MSW to } \\
\text { that of Coal (\%) }\end{array}$ \\
\hline Pekarshing & 10.53 & 11.55 & 6.72 & 9.600 & 24.94 \\
\hline Memelakha & 16.51 & 7.47 & 6.104 & 10.028 & 26.05 \\
\hline Coal & \multicolumn{3}{|l|}{} & 38.5 & 100 \\
\hline
\end{tabular}

\section{Recommendation on waste to energy conversion of MSW}

Based on the energy potential, current study proves that waste can be a source of energy and it can be obtained in the form of biochemical or thermal methods. However, results of this research show that thermal methods are suitable to extract energy from MSW. The bio-degradable waste content was minimum to nil as the waste was segregated at source. The bio-degradable waste from the landfills is mostly taken for composting. The MSW collected at the landfill showed presence of metal content and other incombustible materials which make it uneconomical to convert into refusederived fuel (RDF) (Rezaei et al., 2020). Thus, some of the suitable thermochemical methods to extract energy from the MSW landfills of Pekarshing and Memelakha are Incineration, Pyrolysis and gasification. By 2050, waste generation from two cities will be 1,31,120.52 tons and 6,82,701.84 tons for Phuntsholing and
Thimphu respectively. With WTE Thermal process technologies such as Incineration, Pyrolysis and gasification, it can reduce large quantities of waste in the landfills. The incineration conversion process can reduce 80 to $90 \%$ (Mukherjee et al., 2020) of waste with $20 \%$ waste residue. Similarly, Pyrolysis and Gasification have high energy efficiency along with 90 to $95 \%$ of waste volume reduction with 5 $\%$ byproduct residue such as syngas. Therefore, thermal conversion process technologies aid greater benefit in the WTE process with the least environmental impact (Mukherjee et al., 2020). Table 3 shows accumulation of waste at two landfills corresponding to the growth of the population of two cities by the year 2050 (Thimphu and Phuntsholing) and waste volume reduction by using WTE conversion technologies. As per the energy content analysis of waste, pyrolysis and gasification are recommended to convert MSW to energy.

Table 3: MSW volume reduction by 2050

\begin{tabular}{|l|l|l|l|l|}
\hline \multirow{2}{*}{$\begin{array}{l}\text { Landfill } \\
\text { Location }\end{array}$} & $\begin{array}{l}\text { Quantity of Waste } \\
\text { Generated by year } \\
\text { 2050 (tons) }\end{array}$ & $\begin{array}{l}\text { Thermal } \\
\text { Process } \\
\text { Technology }\end{array}$ & $\begin{array}{l}\text { Waste Residue } \\
\text { (ash) \% }\end{array}$ & $\begin{array}{l}\text { Waste Residue (Volume of } \\
\text { Ash in tons) }\end{array}$ \\
\hline \multirow{2}{*}{$\begin{array}{l}\text { Pekarshing } \\
\text { (Phuntsholing) }\end{array}$} & \multirow{2}{*}{131120.52} & Incineration & 20 & 26224.10 \\
\cline { 3 - 5 } & Pyrolysis & 5 & 6556.03 \\
\cline { 2 - 5 } $\begin{array}{l}\text { Maymaylakha } \\
\text { (Thimphu) }\end{array}$ & \multirow{2}{*}{682701.84} & Gasification & 5 & 6556.03 \\
\cline { 3 - 5 } & Incineration & 20 & 136540.37 \\
\cline { 2 - 5 } & Pyrolysis & 5 & 34135.09 \\
\cline { 2 - 4 } & Gasification & 5 & \\
\hline
\end{tabular}

\section{Conclusion}

Efficient waste management remains a major issue in every nation. MSW waste in Bhutan is segregated at source into biodegradable and nonbiodegradable. The biodegradable waste is taken for composting while the non-degradable waste is taken to the landfill area and dumped in the open space. The non-degradable waste dumped in the landfills are accumulated which leads to numerous

environmental issues. Thus, proper management at the landfill is required. From the waste composition analysis, it is found that there is huge content of non- biodegradable material $(60 \%$ and $40 \%$ for Pekarshing and Memelakha respectively). That can be recycled, reduced and reused if it is properly segregated at the source. If the $3 \mathrm{R}$ (reduce, reuse and reduction) method is strictly followed it can 


\section{Choden et al.}

help in reducing the volume of waste dumped in landfills and can also be the source of income. For example, Memelakha landfill contains $33.39 \%$ of paper, which can be used as a raw material for egg tray manufacture. Major cities in Bhutan like Thimphu are densely populated and have a population growth rate of $1.3 \%$ and a waste generation rate of $1.4 \%$. Phuentsholing which is another highly populated city shows a linear relationship in the increase of population and waste generation rate of $0.7 \%$. By the end of the year 2050, landfill at Pekarshing (Phuentsholing) will accumulate 4,725,892 tons of MSW and Memelakha (Thimphu) will accumulate 27,831,506 tons of MSW. The accumulation of untreated MSW at the landfill is accompanied by waste management issues. Analysis carried out in this research, namely waste composition, proximate and chemical analysis proved that there is energy potential in both the landfills of Pekarshing and Memelakha. The average energy potential of Pekarshing landfill is around $9.6 \mathrm{MJ} / \mathrm{kg}$ which is $24.94 \%$ HHV of that of coal. Similarly, the Memelakha landfill at Thimphu has an average

\section{References}

Agamuthu, P. 2013. "Landfilling in Developing Countries." Waste Management and Research 31(1): 1-2.

ASTM D5231-92(2003). 2003. "ASTM D5231-92(2003), Standard Test Method for Determination of the Composition of Unprocessed Municipal Solid Waste", ASTM International, West Conshohocken, PA.

D240-19, ASTM. 2019. "ASTM D240-19, Standard Test Method for Heat of Combustion of Liquid Hydrocarbon Fuels by Bomb Calorimeter", ASTM International, West Conshohocken, $P A$.

E1755, ASTM. 2020. “ASTM E1755-01(2020), Standard Test Method for Ash in Biomass", ASTM International, West Conshohocken, $P A$.

E872-82, ASTM. 2019 "Standard Test Method for Volatile Matter in the Analysis of Particulate Wood Fuels", ASTM International, West Conshohocken, PA.

Eggleston H.S., Miwa K., Srivastava N. and Tanabe K. 2007. "IPCC 2008, IPCC 2006 Guidelines for National Green House Gas Inventories". Retrieved: http://www.ipccnggip.iges.or.jp. energy potential of $10.03 \mathrm{MJ} / \mathrm{kg}$ which is $26.05 \%$ HHV of that of coal. Based on WTE conversion technique, energy potential at the landfill of Memelakha can produce a power of $5.16 \mathrm{MW}$ and it will gradually increase to $8.85 \mathrm{MW}$ by the year 2050. Similarly, Pekarshing landfill can currently generate power of $1.14 \mathrm{MW}$ and it is estimated to generate $1.44 \mathrm{MW}$ by the year 2050. Several options for the waste to energy conversion technologies are available like incineration, gasification, Pyrolysis, refuse-derived fuel (RDF) etc. These conversion technologies can extract energy from the MSW and aid in efficient waste management.

\section{Future Recommendation}

This research covers the estimation of energy potential of MSW from the landfill sites of two major cities of Bhutan but it is not limited to followings: (i) WTE of MSW generated from source to dumpsites of the country. (ii) Cost benefit analysis of WTE technology (iii) Quantification of greenhouse gases from MSW dumpsites and their energy potential etc.

World Bank. 2018."What a waste 2.0, A global snapshot of Solid waste managament to 2050".Retrieved: https://openknowledge.worldbank.org/handle/10986/30317.

Gross National Happiness Comission. 2019. "Twelfth Five Year Plan (2018-2023) Phuentsholing Thromde".Retrieved: $\quad$ http://www.gnhc.gov.bt/en/wpcontent/uploads/2019/05/12th-FYP_Vol-III_Phuentsholing Thromde.pdf.

Gupta, S., Mohan, K., Prasad, R., Gupta, S., \& Kansal, A. 1998. Solid waste management in India: options and opportunities. Resources conservation and recycling, 24(2), 137-154..

Matsakas, L., Gao, Q., Jansson, S., Rova, U., \& Christakopoulos, P. 2017. Green conversion of municipal solid wastes into fuels and chemicals. Electronic Journal of Biotechnology, 26, 69-83.

Menikpura, Nirmala, Benedict Francis, and Antony Basnayake. 2007. "Application of Waste to Energy Concept Based on Experimental and Model Predictions of Calorific Values for Enhancing the Environment of Kandy City Estimations and Mathematical Model Predictions of Energy." Tropical Agricultural Research Vol. 19: 389 - 400.

Moya, Diego, Clay Aldás, Germánico López, and Prasad Kaparaju. 2017. "Municipal Solid Waste as a Valuable

GNHC. 2000. "Bhutan nationa human development". Retrived: https://www.gnhc.gov.bt/en/wpcontent/uploads/2017/05/nhdr2000.pdf. 


\section{Estimation of energy content in municipal solid waste}

Renewable Energy Resource: A Worldwide Opportunity of Energy Recovery by Using Waste-To-Energy Technologies." Energy Procedia 134: 286-95. https://doi.org/10.1016/j.egypro.2017.09.618.

Mukherjee, C., Denney, J., Mbonimpa, E. G., Slagley, J., \& Bhowmik, R. 2020. A review on municipal solid waste-toenergy trends in the USA. Renewable and Sustainable Energy Reviews, 119, 109512.

National Environment Commission. 2016. "Royal Government of Bhutan State of the Environment Report". Retrieved :www.nec.gov.bt.

National Statistics Bureau. 2018. "National Report 2017 Population and Housing Census of Bhutan". Retrieved: www.nsb.gov.bt.

Penjor, Sonam. 2019. "Fighting Waste with Waste- the Story of Phuntsholing Landfill." Bhutan Broadcast Service. http://www.bbs.bt/news/?p=114287.

Phuntsho, Sherub, Ichharam Dulal, Dechen Yangden, and Ugyen M Tenzin. 2010. "Studying Municipal Solid Waste Generation and Composition in the Urban Areas of Bhutan." Waste Management \& Research, 28: 545-551. DOI: 10.1177/0734242X09343118 (December 2008): 54551.

Van Prevelen, D. 2007. "Coal Typology and Conversion Factors.” Applied energy (8): 514.

Rai, Rajesh. 2021. "Phuentsholing Adopts Japanese Landfill System." Kuensel. https://kuenselonline.com/phuentsholing -adopts-japanese - landfill-system/.
Rezaei, Hamid, Fahimeh Yazdan Panah, C. Jim Lim, and Shahab Sokhansanj. 2020. "Pelletization of Refuse-Derived Fuel with Varying Compositions of Plastic, Paper, Organic and Wood." Sustainability (Switzerland) 12(11): 1-11.

Royal Government of Bhutan. 2017. "Population \& Housing Census of Bhutan Chukha". Retrieved http://www.amisdubhoutan.fr/page02zq/PHCB2017_natio nal.pdf:

Royal Society for Protection of Nature.2018." Policy Framework for Solid Waste Management". Retrived: http://www.rspnbhutan.org/wpcontent/uploads/2018/07/Public-Private-Partnership-forUrban-Environment.pdf.

S. Manuja, A.Kumar, S.Pandey. 2018. "Greenhouse Gas Emissions from the Informal Sector in India." International Journal of Latest Engineering Research and Applications (IJLERA) 3(1): 17-26.

Sahito, Abdul Razaque, Rasool Mahar, Zuhaib Siddiqui, and Khan Muhammad Brohi. 2013. "Estimating Calorific Values of Lignocellulosic Biomassfrom Volatile and Fixed Solids." International Journal of Biomass \& Renewables (Cv): 1-6.

University of Washington. 2005. "Energy Content of Fuels." Hand Out: 1-10. Retrived :www.ocean.washington.edu/courses/envir215/energynu mbers.

Yeshi Choden, M.P. Sharma. 2020. "Energy Potential of MSW of Roorkee City."' Indian Journal of environmental protection 40(4): 408-12. 